\title{
Mesodermal ALK5 controls lung myofibroblast versus lipofibroblast cell fate
}

\author{
Aimin Li', Shudong Ma', Susan M. Smith', Matt K. Lee ${ }^{1}$, Ashley Fischer ${ }^{1}$, Zea Borok ${ }^{2,3}$, Saverio Bellusci ${ }^{1,4,5}$, \\ Changgong Li ${ }^{1}$ and Parviz Minoo ${ }^{1,3^{*}}$
}

\begin{abstract}
Background: Epithelial-mesenchymal cross talk is centerpiece in the development of many branched organs, including the lungs. The embryonic lung mesoderm provides instructional information not only for lung architectural development, but also for patterning, commitment and differentiation of its many highly specialized cell types. The mesoderm also serves as a reservoir of progenitors for generation of differentiated mesenchymal cell types that include aSMA-expressing fibroblasts, lipofibroblasts, endothelial cells and others. Transforming Growth Factor $\beta$ (TGF $\beta$ ) is a key signaling pathway in epithelial-mesenchymal cross talk. Using a cre-loxP approach we have elucidated the role of the TGF $\beta$ type I receptor tyrosine kinase, ALK5, in epithelial-mesenchymal cross talk during lung morphogenesis.

Results: Targeted early inactivation of Alk5 in mesodermal progenitors caused abnormal development and maturation of the lung that included reduced physical size of the sub-mesothelial mesoderm, an established source of specific mesodermal progenitors. Abrogation of mesodermal ALK5-mediated signaling also inhibited differentiation of cell populations in the epithelial and endothelial lineages. Importantly, Alk5 mutant lungs contained a reduced number of aSMA ${ }^{\text {pos }}$ cells and correspondingly increased lipofibroblasts. Elucidation of the underlying mechanisms revealed that through direct and indirect modulation of target signaling pathways and transcription factors, including PDGFRa, PPARY, PRRX1, and ZFP423, ALK5-mediated TGF $\beta$ controls a process that regulates the commitment and differentiation of aSMA ${ }^{\text {pos }}$ versus lipofibroblast cell populations during lung development.
\end{abstract}

Conclusion: ALK5-mediated TGF $\beta$ signaling controls an early pathway that regulates the commitment and differentiation of aSMA ${ }^{\text {pos }}$ versus LIF cell lineages during lung development.

Keywords: Lipofibroblast, Lung development, Mesoderm, Myofibroblast, Pdgfra, Pparß, Zfp423

\section{Background}

In mammals, the anterior foregut invades the surrounding splanchnic mesoderm to form the primordial lung. During embryogenesis, this bilayered structure undergoes a series of highly orchestrated morphogenetic steps to form a complex respiratory organ purported to include over 40 specialized cell varieties. Elucidating the mechanisms that govern commitment and differentiation of these cell types has been a major challenge. The bulk of the cell types studied has been of endodermal origin. Much less is known about the regulatory

\footnotetext{
* Correspondence: minoo@usc.edu

${ }^{1}$ Division of Newborn Medicine, Department of Pediatrics, LAC+USC Medical Center and Childrens Hospital Los Angeles, Keck School of Medicine of USC, Los Angeles, CA 90033, USA

${ }^{3}$ Hastings Center for Pulmonary Research, Keck School of Medicine of USC, Los Angeles, CA 90033, USA

Full list of author information is available at the end of the article
}

mechanisms that control the ontogeny and differentiation of the mesodermally-derived cell varieties.

In very broad terms, the lung mesenchyme can be divided into two histologically distinct cell populations that are detectable as early as E13.5 [1]. The 'sub-epithelial mesenchymal' cells wrap around the epithelial ducts, while the 'sub-mesothelial mesenchymal' (SMM) cells inhabit the area between the mesothelium and the subepithelial mesenchymal cells $[1,2]$. SMM is a major site of Fgf10 expression. We and others have shown that Fgf $10^{\text {pos }}$ cells contribute, but are not the sole source of smooth muscle (SM) cells and lipofibroblasts (LIFs) [2, 3]. Viewed from the perspective of gene expression, mesodermal derivatives can be simply grouped into two molecularly defined cell populations; the $\alpha \mathrm{SMA}^{\mathrm{pos}}$ and $\alpha \mathrm{SMA}^{\text {neg }}$ groups. The primary $\alpha \mathrm{SMA}^{\mathrm{pos}}$ group comprises the fibroblasts in the peribronchial (airway) and perivascular SM 
layers as well as interstitial $\alpha \mathrm{SMA}^{\text {pos }}$ myofibroblasts. Notably, the latter cells attain $\alpha \mathrm{SMA}^{\mathrm{pos}}$ status at different times during lung development. While airway and perivascular SM cells are $\alpha \mathrm{SMA}^{\mathrm{pos}}$ as early as E11.5, interstitial fibroblasts begin to display $\alpha \mathrm{SMA}$ only in mid to late gestation. With that caveat in mind, in the present study we have opted to use the term ' $\alpha \mathrm{SMA}^{\text {pos }}$ cells' in a 'broad stroke' to conveniently refer collectively to all cells that express this marker and not solely the 'interstitial myofibroblasts' noted routinely by other investigators.

Generation of mesodermal cell diversity occurs concurrently with the structural development of the lung. A central player is the reciprocal communication known as epithelial-mesenchymal interactions that occur between the foregut endoderm and the lateral plate mesodermderived splanchnic mesenchyme. This process works on a 'signaling, transcription factors, signaling' algorithm [4-6]. Additional integral components include the extracellular matrix, structural proteins and differentiationspecific proteins. A major signaling pathway in the lung and other mammalian organs is the transforming growth factor beta (TGF $\beta$ ) family of secreted polypeptides.

The significance of TGF $\beta$ signaling during development and disease can be hardly overstated. TGF $\beta$ is the prototype of a family of secreted dimeric peptide growth factors that includes the TGF $\beta$ s, activins, inhibins, and bone morphogenetic proteins [7]. In vertebrates, TGF $\beta$ regulates key processes in stem cell maintenance, organogenesis, wound healing, and homeostasis. Given this broad range of activity, it is not surprising that TGF $\beta$ dysregulation results in a spectrum of pathologies ranging from cancer to pulmonary fibrosis.

The TGF $\beta$ machinery has many "moving parts. The ligands are produced as 'latent' peptides. Upon secretion and activation, all three TGF $\beta$ s signal by engaging a specific receptor, composed of two related transmembrane serine/threonine kinases, called the type I and type II TGF $\beta$ receptors (T $\beta R 1$, or ALK5 and T $\beta R 2$ ) [8]. The basic mechanism of receptor activation involves binding of the ligand to T $\beta R 2$, followed by recruitment of ALK5. Recruitment triggers ALK5 kinase activity, transducing the signal by phosphorylating and activating members of the SMAD family of transcription factors [8].

In various tissues, TGF $\beta$ response is remarkably cell type and context dependent. It is equally true that the downstream effects of TGF $\beta$ are transduced not simply via a single target, but may involve multiple nodes. Given the multicomponent nature of the pathway, there is a wide spectrum of versatility and selectivity in TGF $\beta$ biologic functions. Some are ostensibly paradoxical. For example, TGF $\beta$ acts as both a cancer promoter and suppressor [9]. Selective utilization of receptors is a potential mechanism for generating versatility in TGF $\beta$ function. TGF $\beta$ expression is thought to be ubiquitous throughout the lung with both endodermal and mesodermal cells displaying ALK5 and T $\beta R 2$. Elucidating the function of each receptor in specific cell types and in particular in endodermal versus mesodermal cells of the lung is a necessary step towards unlocking the precise roles of TGF $\beta$ in development and disease. Attempts to define the specific role played by each of the receptors using targeted germline deletions of either $T \beta r 2$ or $A l k 5$ have not been fully successful due to early embryonic lethality $[10,11]$. Using conditional inactivation, we have shown that lack of mesodermal-specific T $\beta R 2$ causes embryonic lethality, while endodermal $T \beta r 2$ inactivation is not only tolerated and viable, but protects against experimentally induced fibrosis and bronchopulmonary dysplasia $[12,13]$. A systematic approach involving abrogation of each receptor on a cell-type specific basis has the promise of revealing the precise roles of each receptor during embryonic development.

In this study, Alk5 was specifically inactivated in the early embryonic multipotential mesoderm that is the origin of lung mesodermal progenitors. Alk $5^{\text {Dermo1 }}$ mice displayed multiple abnormalities and postnatal lethality. Their lungs were structurally immature (pulmonary hypoplasia), characterized by thickened mesenchymal walls around significantly reduced alveolar spaces. Importantly, the studies revealed a novel role for ALK5mediated TGF $\beta$ signaling that regulates the balance between $\alpha \mathrm{SMA}^{\mathrm{pos}}$ and LIF cell fate commitment and differentiation during lung development. The precise balance between these key cell populations is critical to normal lung development and its disruption underlies the pathobiology of serious pulmonary disorders.

\section{Results}

\section{Mesodermal-specific Alk5 inactivation}

The localization and efficiency of LoxP-dependent excision in Dermo1-cre (aka, Twist2-cre) mouse lungs has been previously reported [14, 15]. Dermo1-driven, Cre-mediated recombination occurs early and exclusively throughout the tracheal and pulmonary mesoderm, but not in the epithelium (Additional file 1A-C). Accordingly, we generated triple transgenic Dermo1cre;Alk5 $5^{\text {flox flox }} ; m$ TmG mice (Methods) in which exon 3 of the Alk5 gene is excised in early pulmonary mesodermal progenitors (Additional file 1D). Over 800 fetuses at various embryonic stages were genotyped and analyzed (Additional file 1E).

Heterozygous Alk5 $5^{f l o x / w t}$;Dermo1-Cre; $m$ TmG mice were born alive and had no discernable abnormalities in development, growth, or reproduction. Homozygous Alk5 $5^{\text {flox/flox }}$;Dermo1-Cre; $m$ TmG (hereafter Alk $5^{\text {Dermo1 }}$ ) embryos examined at E11.5 showed no obvious morphological defects. Defects in body-wall closure in Alk $5^{\text {Dermo1 }}$ embryos, as previously reported [16], were 
evident at E12.5 (data not shown). Embryonic lethality occurred between E14.5 and E18.5. Occasionally, mutant embryos with a less severe phenotype survived to birth but died immediately afterwards.

To confirm deletion of Alk5 from the pulmonary mesoderm, expression of ALK5, phospho-SMAD2 (p-SMAD2), and PAI-1 were assessed by immunoblotting. The latter is expressed by mesenchymal cells in response to canonical TGF $\beta$ signaling. Compared to controls, ALK5 was decreased by nearly $85 \%(0.15 \pm 0.013)$, p-SMAD 2 by $73 \%(0.23 \pm 0.02)$, and PAI-1 expression reduced by $83 \%(0.17 \pm 0.05)$ (Additional file $1 \mathrm{~F})$. Immunohistochemistry (IHC) for ALK5 and PAI-1 on E15.5 lung sections confirmed decreased mesenchymal and intact epithelial ALK5 immunoreactivity (Additional file 1G-J). While these results confirm abrogation of canonical TGF $\beta$ signaling, the source of the residual activity can be certainly attributed to intact signaling in the lung epithelium.

\section{Lung immaturity and blocked epithelial and endothelial cell differentiation in Alk5 ${ }^{\text {Dermo1 }}$ lungs}

The lungs of E18.5, Alk5 $5^{\text {Dermo1 }}$ embryos were smaller and poorly expanded, but the number of lobes appeared normal (Additional file 2A-D and data not shown). The alveolar diameters were decreased and septal thicknesses increased relative to control lungs (Additional file 2E-J). Glycogen stores, which are an epithelial marker of immature lungs [17], were also increased in $A l k 5^{\text {Dermo1 }}$ lungs (Additional file 2G,J). IHC using antibodies against acetylated tubulin, CC10, pro-SPC, and T1a (specific to ciliated cells, Clara cells, alveolar epithelial type II cells, and alveolar epithelial type 1 cells, respectively) showed reduced differentiation of all four major epithelial cell types in E18.5 Alk5 ${ }^{\text {Dermo1 }}$ lungs (Additional file $3 \mathrm{~A}-\mathrm{H}$ ). These findings were also examined by quantitative PCR (Q-PCR) (Additional file 3I). Cumulatively, these results suggest that lung maturation and epithelial cell differentiation are delayed by mesenchymal Alk5 inactivation.

The lung mesoderm serves as the origin of endothelial cells that form the pulmonary vasculature. Flk1, expressed by vascular endothelial progenitors, was reduced in E13.5 Alk5 $5^{\text {Dermol }}$ lungs as was the fraction of $\mathrm{CD} 34^{\text {pos }}$ cells (Additional file 3J-M). As lung development progressed, PECAM1, a vascular endothelial differentiation marker, was also reduced. The distal capillary plexus adjacent to the airway epithelium was less dense compared to age-matched controls (Additional file $3 \mathrm{~N}-\mathrm{Q}$ ). However, the large blood vessels were intact (Additional file 3P,Q, Arrows). Q-PCR of multiple vascular markers showed that in $A l k 5^{\text {Dermo1 }}$ lungs, Pecam-1 mRNA was $0.58 \pm 0.19(P<0.05)$, Flk1 was $0.63 \pm 0.18(P<0.05)$, and Flt-1was $0.67 \pm 0.15(P<0.05)$ of controls (Additional file 3R). However, mutant and control lungs had similar
Flt-4 $(0.83 \pm 0.23, P>0.05)$ and Vegfa $(0.78 \pm 0.23, P>0.05)$ mRNAs.

\section{Mesodermal-specific Alk5 inactivation reduces the sub-mesothelial mesenchyme}

Structurally, the SMM [15] of Alk5 $5^{\text {Dermol }}$ lungs was smaller and more irregularly shaped compared to control lungs (Fig. 1a-e and Additional file 4). Antiphospho-histone H3 labeling revealed fewer mitotic cells within the distal mesenchyme of mutant lungs $(2.02 \%$ vs. $0.6 \%)$. The SMM regulates epithelial, smooth muscle, and vascular development by producing factors such as FGF10 [18]. FGF10 mRNA in mutant lungs was $0.63 \pm 0.02$ of controls (Fig. 1g). In addition, Fgf9 made by the mesothelium/epithelium and $\mathrm{Fgf7}$ expressed by the mesenchyme were respectively expressed at $0.84 \pm 0.04$ and $0.58 \pm 0.05$ of controls (Fig. 1g). To assess the functional significance of the reduced $F g f 10$ and $F g f 9$ mRNAs, we examined expression of their target genes. Immunoblotting revealed decreased SPRY2 and SPRY4 in Alk $5^{\text {Dermol }}$ lungs relative to controls, confirming functionally reduced FGF10 signaling (Fig. 1h). Similarly, there was profound decrease in the homeodomain transcription factor PITX2, a major target of FGF9 (Fig. 1h). These data suggest that mesodermal Alk5 inactivation reduces SMM volume by decreasing overall functional FGF signaling.

\section{Inhibition of airway smooth muscle development}

FGF10 ${ }^{\text {pos }}$ cells contribute to differentiated peribronchial smooth muscle (PBSM) cells [3]. By IHC, layers of $\alpha$ SMA $^{\text {pos }}$ PBSM were thinner in diameter and included large gaps in E18.5 mutant lungs (Fig. 2a-h). However, $\alpha$ SMA expression around large blood vessels was similar in mutant and control lungs (Fig. 2f, Arrowheads). Consistent with the IHC, Q-PCR showed reduced mRNA for multiple myofibroblast markers in Alk $5^{\text {Dermo1 }}$ lungs (Fig. 2i). These included $\alpha S M A(0.56 \pm 0.85)$, Calponin $(0.67 \pm 0.016), \quad S M-M H C \quad(0.63 \pm 0.016), \quad$ and $\quad S M 22 \alpha$ $(0.71 \pm 0.18)$. In addition, there was reduced mRNA for both Pdgfr $\alpha(0.45 \pm 0.021)$ and Pdgfr $\beta(0.625 \pm 0.073)$. Transcripts for NOGGIN, an airway smooth muscle cell marker [19, 20], were also decreased (Fig. 2j, $0.39 \pm 0.1$ of controls, $P<0.05)$ while those for Heyl, a vascular smooth muscle marker $[20,21]$, were only slightly reduced (Fig. 2j, $0.71 \pm 0.078$ of controls, $P<0.05$ ). Thus, the diminished $\alpha \mathrm{SMA}^{\mathrm{pos}}$ cells in Alk5 $5^{\text {Dermol }}$ lungs were primarily lost from the PBSM layers. In addition, there was decreased mRNA for paired-homeobox transcription factor PRRX1 $(0.7 \pm 0.056$ of controls, $P<0.05)$ and the extracellular matrix glycoprotein TENASCIN-C (TNC; $0.53 \pm 0.047$ of controls, $P<0.01$ ), both of which promote myofibroblast growth and differentiation (Fig. 2k). The effects of ALK5 abrogation on $\alpha S_{M A}{ }^{\text {pos }}$ 


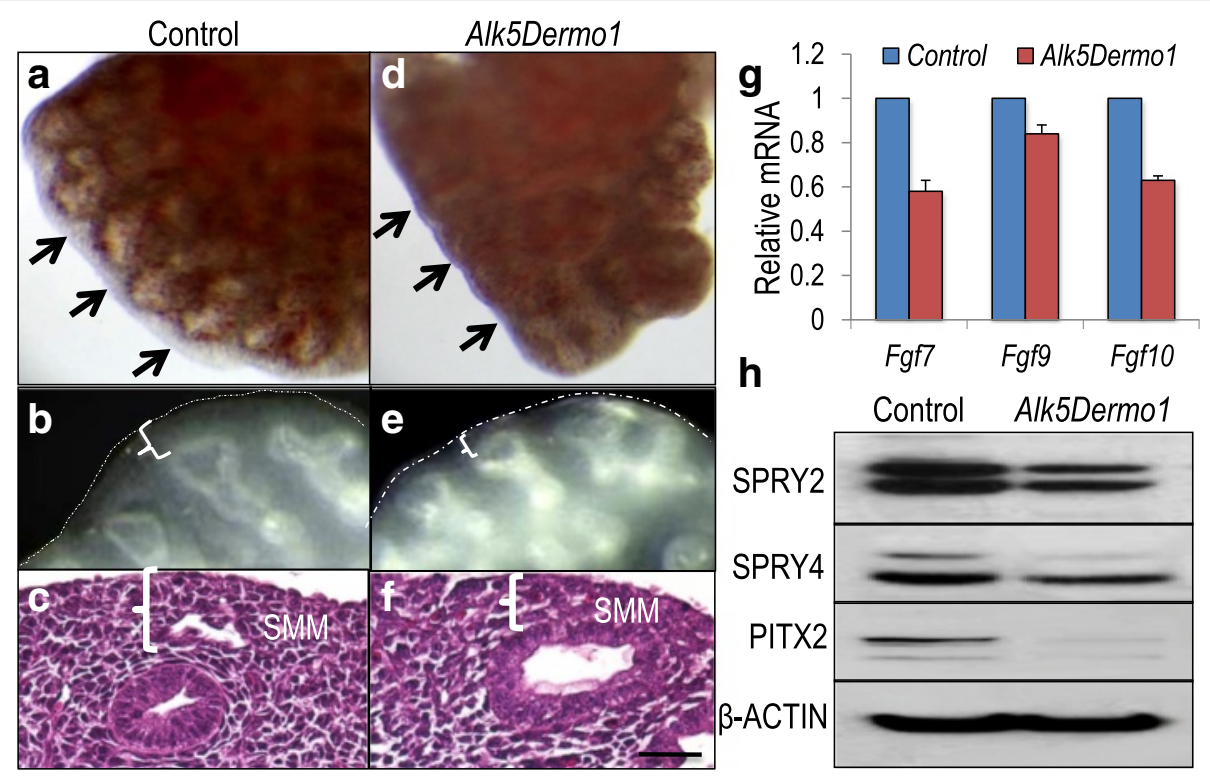

Fig. 1 Mesodermal progenitor-specific deletion of Alk5 reduced the sub-mesothelial mesenchyme. (a-f) Gross morphology (a, d, b, and e) and hematoxylin and eosin staining (c and $\mathbf{f}$ ) show decreased sub-mesothelial mesenchyme in $A / k 5^{\text {Dermol }}$ mutant lungs at E12.5 (b, e, c, and $\mathbf{f}$ ) or E13.5 (a and d). (g) Quantitative PCR showed decreased Fgf 7, Fgf9, and Fgf10 mRNA in E13.5 Alk5 Dermo1 lungs; $n=2$ controls and 3 mutant lungs. (h) Western blot analysis showed decreased FGF signaling target genes. $\beta$-ACTIN was used as control, $n=3$. Error bars show standard deviation. Scale bar: $f=20 \mu \mathrm{m}$

cell commitment was also assessed by analysis of PDGFR $\alpha$ protein (Fig. 3a-f), which is regulated by TNC and highly expressed on $\alpha$ SMA $^{\text {pos }}$ cell precursors [22]. The fraction of PDGFR ${ }^{\text {pos }}$ cells surrounding the airway epithelium was significantly reduced in $A l k 5^{\text {Dermo1 }}$ lungs (Fig. 3d-f), and western blot analysis confirmed the decrease in $\alpha$ SMA and PDGFR $\alpha$ (Fig. 3g, i). Consistent with this observation, phosphorylation of AKT, the canonical substrate of PDGFA-activated PDGFR $\alpha$ [23-25], was reduced in both Alk5 $5^{\text {Dermol }}$ lung homogenates (Fig. $3 g$ ) and isolated primary Alk5 $5^{\text {Dermo1 }}$ mesenchymal cells (Fig. 3h). Thus, ALK5-mediated TGF $\beta$ signaling is required in lung $\alpha \mathrm{SMA}^{\mathrm{pos}}$ cell development, and early defects in this pathway lead to decreased populations of cells expressing $\alpha$ SMA or PDGFR $\alpha$.

\section{Lipofibroblast (LIF) hyperplasia in Alk5 $5^{\text {Dermo1 }}$ lungs}

In addition to $\alpha \mathrm{SMA}^{\mathrm{pos}}$ and endothelial cells, the multipotential lung mesoderm gives rise to LIFs. In the rat, LIFs are detected on embryonic day E16, increase during gestation, and decline after birth [26]. Oil Red O staining of Alk5 $5^{\text {Dermo1 } 1}$ lungs revealed overwhelmingly abundant LIFs within the developing mesoderm, relative to controls (Fig. 4a-d and Additional file 5). To confirm that observation, Q-PCR was used to quantify the mRNA for multiple LIF markers, including adipocyte transcription factors PPAR $\gamma$ and $\operatorname{CEBP} \alpha$, the lipid droplet-associated Adipose Differentiation-Related Protein (ADRP), and adipocyte Fatty Acid Binding Protein 4 (FABP4). All were elevated in $A l k 5^{\text {Dermo1 }}$ lungs (Fig. 4e). Immunoblots of total Alk5 $5^{\text {Dermo1 }}$ lung homogenates confirmed that ADRP, CEBP $\alpha$, and PPAR $\gamma$ proteins were more abundant compared to controls. Furthermore, p-AKT and p-ERK were decreased while PTEN, a TGF $\beta$-repressed phosphatase associated with LIF hyperplasia [27], was increased in Alk5 $5^{\text {Dermol }}$ lungs (Fig. 4f). Importantly, Zfp 423, which encodes a zinc finger transcription factor that regulates PPAR $\gamma$ in pre-adipocytes [28, 29], as well as WISP2, a matricellular protein that is highly expressed in adipocyte precursors [30, 31], were increased in Alk5 $5^{\text {Dermol }}$ lungs (Fig. 4g). These findings indicate that abrogation of ALK5-mediated signaling increases LIF commitment and differentiation.

\section{Establishment of Alk5-deficient mesodermal cell lines}

The aggregate data presented above suggests that inactivation of Alk5 in multipotential lung mesoderm promotes LIF commitment and inhibits SM differentiation. To examine the underlying mechanisms, we isolated mesodermal cells from Alk $5^{\text {Dermo } 1} ; m \operatorname{Tm} G$ and Alk $5^{f l o x / f l o x} ; m \operatorname{Tm} G$ mouse lungs. These $A l k 5^{-1-}$ and $A l k 5^{+/+}$cells were immortalized by transfection with an SV40 plasmid and purified by FACS (Methods). TGF 3 -induced SMAD2 phosphorylation was nearly absent in $A l \mathrm{kS}^{-/-}$cells, confirming abrogation of ALK5-mediated canonical TGF $\beta$ signaling (Fig. 5a). 


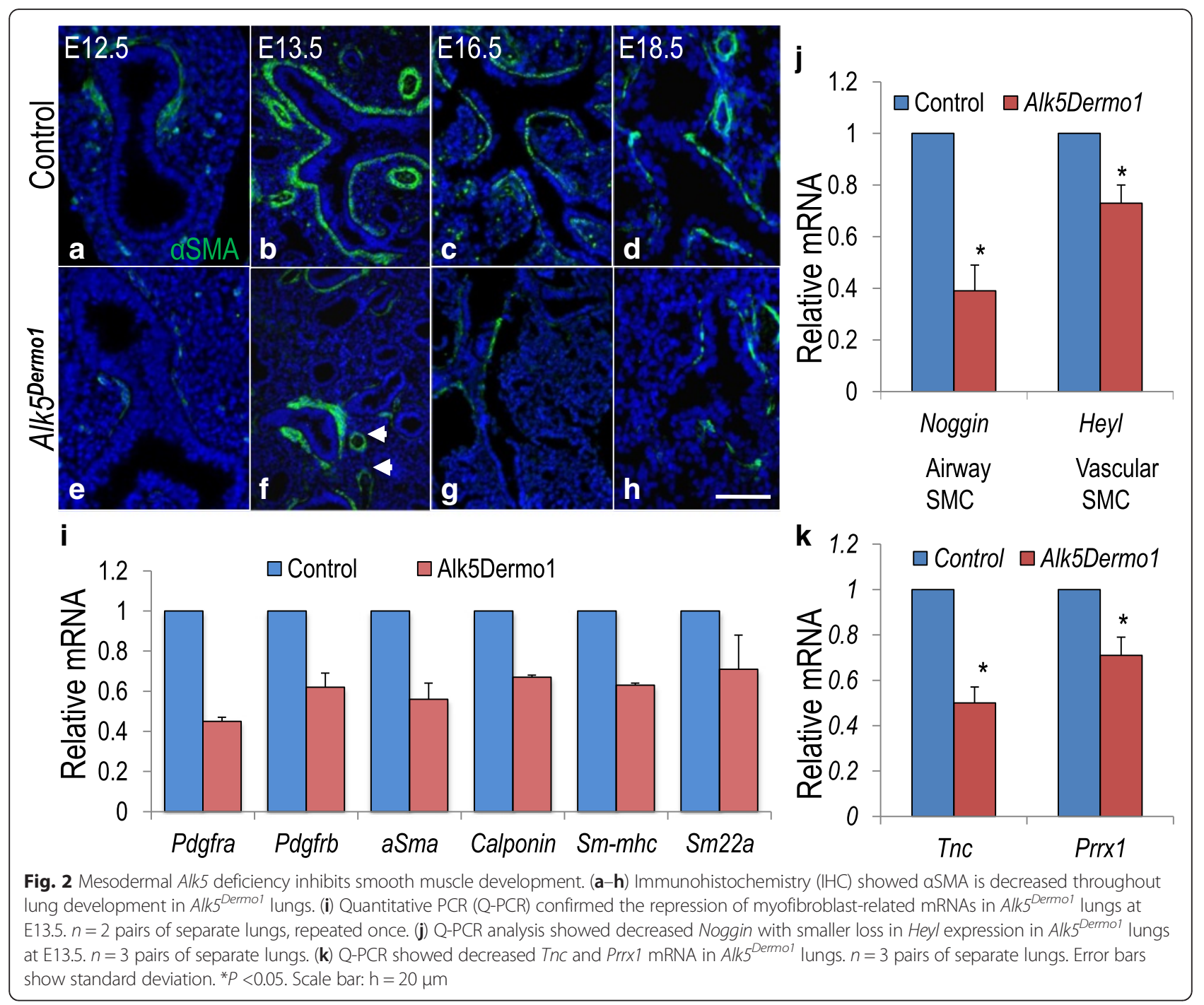

Other mediators of TGF $\beta$ signaling were also affected. Baseline p-P38, p-AKT and p-ERK were high in $A l k 5^{+/+}$ control cells but TGF $\beta$ stimulation minimally induced p38 activation in mutant cells. TGF $\beta$ also had little impact on p-AKT in the mutant cells, but total AKT was reduced. Importantly, baseline ERK phosphorylation was elevated in $A l k 5^{-/}$cells, and TGF $\beta$ induced a robust response in these cells compared to $A l k 5^{+/+}$controls (Fig. 5a). These findings indicate the critical and complex role of ALK5 activity in the TGF $\beta$ signal transduction pathway.

\section{ALK5-mediated TGF $\beta$ represses the LIF transcription factor ZFP423 in vitro}

We also evaluated the impact of TGF $\beta$ on the isolated cells. Treatment with recombinant TGF $\beta(4 \mathrm{ng} / \mathrm{mL}$ for 48 hours, Materials \& Methods) initiated myogenic differentiation as assessed by increased $\alpha S M A$ and Prrx 1 transcripts in $A l k 5^{+/+}$but not $A l k 5^{-/-}$mesenchymal cells
(Fig. 5b-f). In contrast, Tnc induction by TGF $\beta$ was unaffected by Alk5 inactivation, suggesting that its regulation is independent of ALK5 and the canonical TGF $\beta$ pathway. Conversely, Alk5 $5^{-/-}$cells displayed a significantly high rate of spontaneous adipogenic differentiation in non-induced, minimum standard culture medium (Fig. 5g, h). This did not occur in $\mathrm{Alk5}^{+/+}$controls, and was verified by assessing the expression of adipogenic markers. After 5 days in culture, lipogenic mediators, including Adrp, Cebpa and Ppary mRNA, increased by $1.57 \pm 0.34-$, $3.02 \pm 0.7$-, and $3.57 \pm 1.1$-fold, respectively in the $A l k 5^{-1-}$ cells compared to $3.95 \pm 0.68$-, 4.4 \pm 1.0 -, and $8.58 \pm 2.1$-fold in the $A l k 5^{+/+}$cells (Fig. 5i). Likewise, Zfp 423 mRNA was 11-fold higher and Wisp2 mRNA was 17 -fold higher in $A l k 5^{-/}$cells relative to $A l k 5^{+/+}$cells (Fig. 5j). To determine the relationship between TGF $\beta$ and $Z f p 423$, we treated $A l k 5^{+/+}$and Alk $5^{-/}$cells with recombinant TGF $\beta$ ligand $(4 \mathrm{ng} / \mathrm{mL}$ 

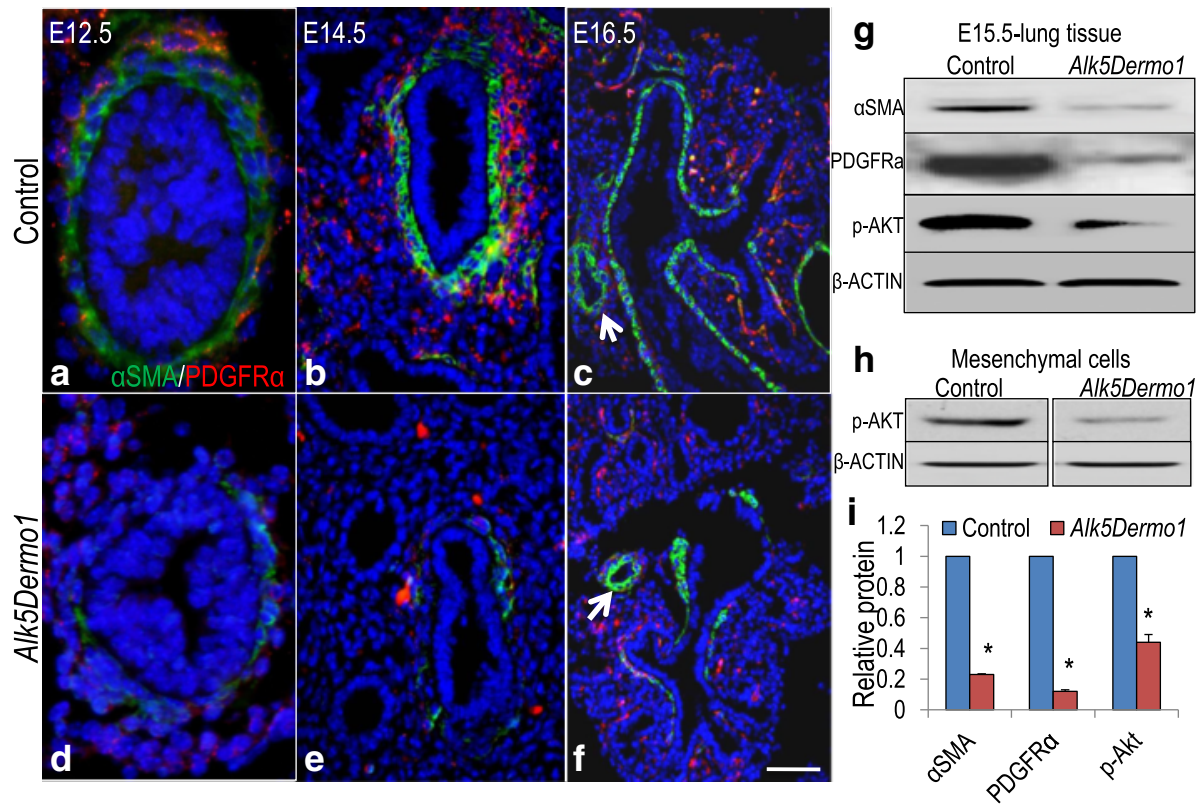

Fig. 3 Mesodermal Alk5 deficiency reduces smooth muscle precursors. (a-f) Immunohistochemistry showed reduced aSMA (green) and PDGFRa (red) in Alk5 $5^{\text {Dermol }}$ lungs throughout lung development. (g) Western blot analysis showed decreased aSMA, PDGFRa and p-AKT protein in E15.5 Alk5 ${ }^{\text {Dermol }}$ whole lung tissue. $\beta$-ACTIN was used as control. $n=3$ separate lungs. (h) Western blot analysis showed decreased $p$-AKT protein in primary mesenchymal cells isolated from E15.5 Alk5 $5^{\text {Dermol }}$ lungs. $n=3$ pairs of separate lungs. $\beta$-ACTIN was used as control. (i) Densitometric analysis of western blot results in $(\mathbf{g})$. Error bars show standard deviation. ${ }^{*} P<0.05$. Scale bar: $\mathrm{f}=20 \mu \mathrm{m}$
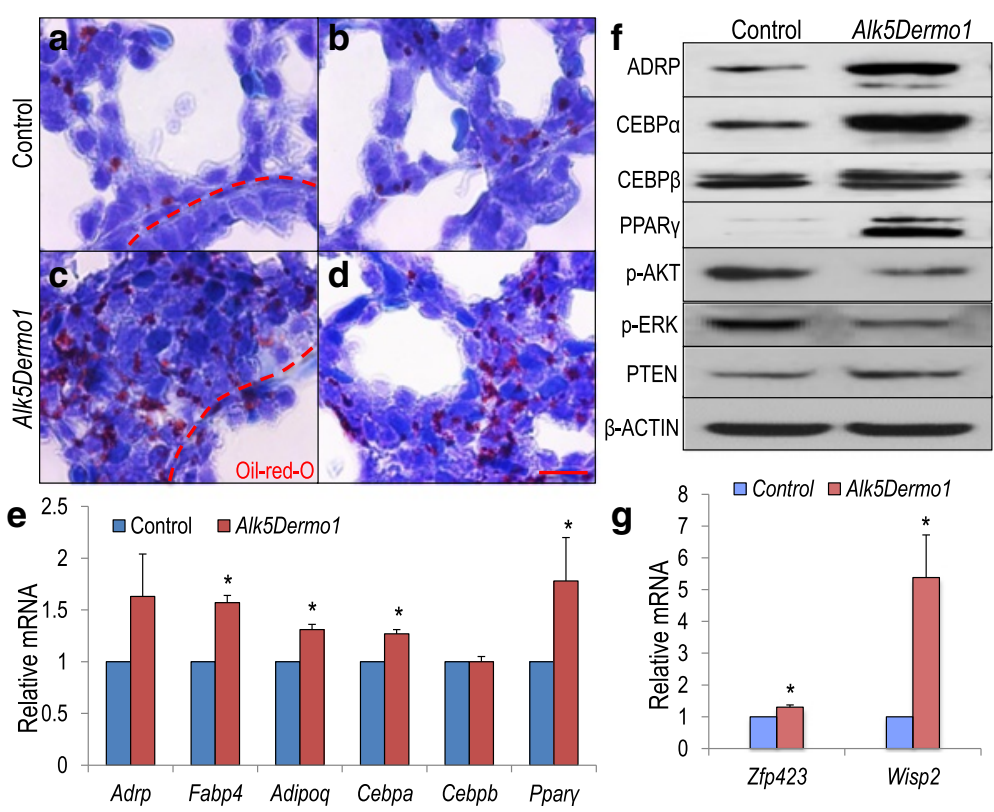

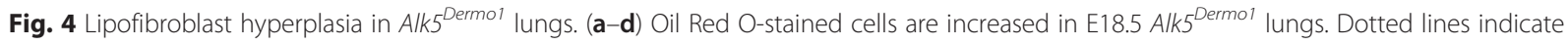
basement membrane between epithelium and surrounding mesenchyme. (e) Quantitative PCR (Q-PCR) showed mRNA for LIF markers increased in E18.5 Alk5 $5^{\text {Dermol }}$ lungs. $n=3$ pairs of independent lungs, Error bars show standard deviation, ${ }^{*} P<0.05$. (f) Western blot analysis confirmed increased LIF markers, $n=6$ pairs of lungs. Western blot analysis also showed decreased $p$-AKT and $p$-ERK, and increased PTEN. $\beta$-ACTIN was

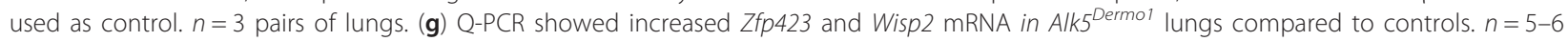
pairs of independent lungs. Error bars show standard error of the mean. ${ }^{*} P<0.05$. Scale bar: $d=10 \mu \mathrm{m}$ 


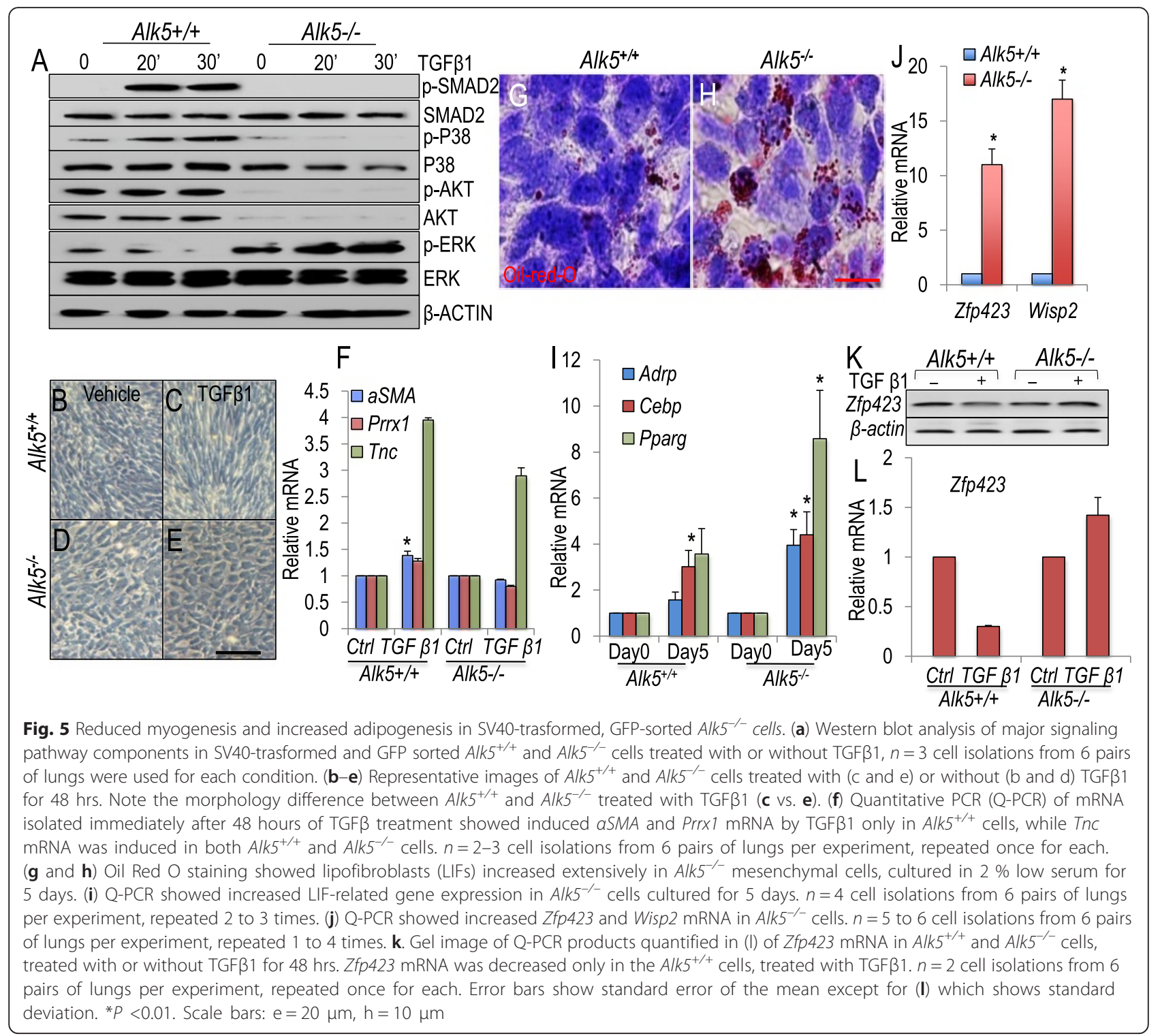

for 48 hours, Materials \& Methods). Controls were treated exactly the same with the exception of bovine serum albumin (BSA) replacing TGF $\beta$. TGF $\beta$ repressed Zfp 423 mRNA levels and this activity was dependent on ALK5 (Fig. 5k, 1). Taken together, these data indicate a novel mechanism by which abrogation of ALK5-mediated canonical TGF $\beta$ signaling, through regulation of Z $f p 423$, promotes LIF versus $\alpha S M A^{\text {pos }}$ cell differentiation in lung mesodermal cells.

\section{The role of PDGFRa}

As noted above, PDGFR $\alpha$ and signaling were decreased in Alk $5^{\text {Dermo1 }}$ lungs (Fig. 3). Although PDGFR ${ }^{\text {pos }}$ cells can differentiate into either $\alpha S M A^{\text {pos }}$ cells or LIFs, their role in determining mesodermal commitment has not been elucidated. We therefore sought to determine whether PDGFA signaling through PDGFR $\alpha$ is necessary for $A l k 5$ to induce $\alpha S M A^{\text {pos }}$ cell differentiation. TGF $\beta$ is known to induce $P d g f r \beta$; however, its role in regulating Pdgfr $\alpha$ remains unknown. Because PDGFR $\alpha$ is decreased in $A l k 5^{\text {Dermo1 }}$ mutant lungs, its possible regulation by TGF $\beta$ was evaluated by TGF $\beta$ treatment $(4 \mathrm{ng} / \mathrm{mL}$, Materials \& Methods) for 48 hours. Controls were treated exactly the same with the exception of BSA replacing TGF $\beta$. TGF $\beta$ increased both $P d g f r \alpha$ and $P d g f r \beta$ mRNAs in $A l k 5^{+/+}$cells but not in Alk5 $5^{-/-}$cells (Fig. 6a) indicating that TGF $\beta$ regulation of Pdgfr $\alpha$ and, hence, $\alpha \mathrm{SMA}^{\mathrm{pos}}$ cell differentiation, requires ALK5 activity. Surprisingly, Pdgfra mRNA increased during spontaneous differentiation of $A l k 5^{-1-}$ cells to LIFs over a 5 day period (Fig. 6b). In addition, PDGFR $\alpha$ protein was consistently higher in $A l k 5^{-/-}$compared to $A l k 5^{+/+}$cells on 

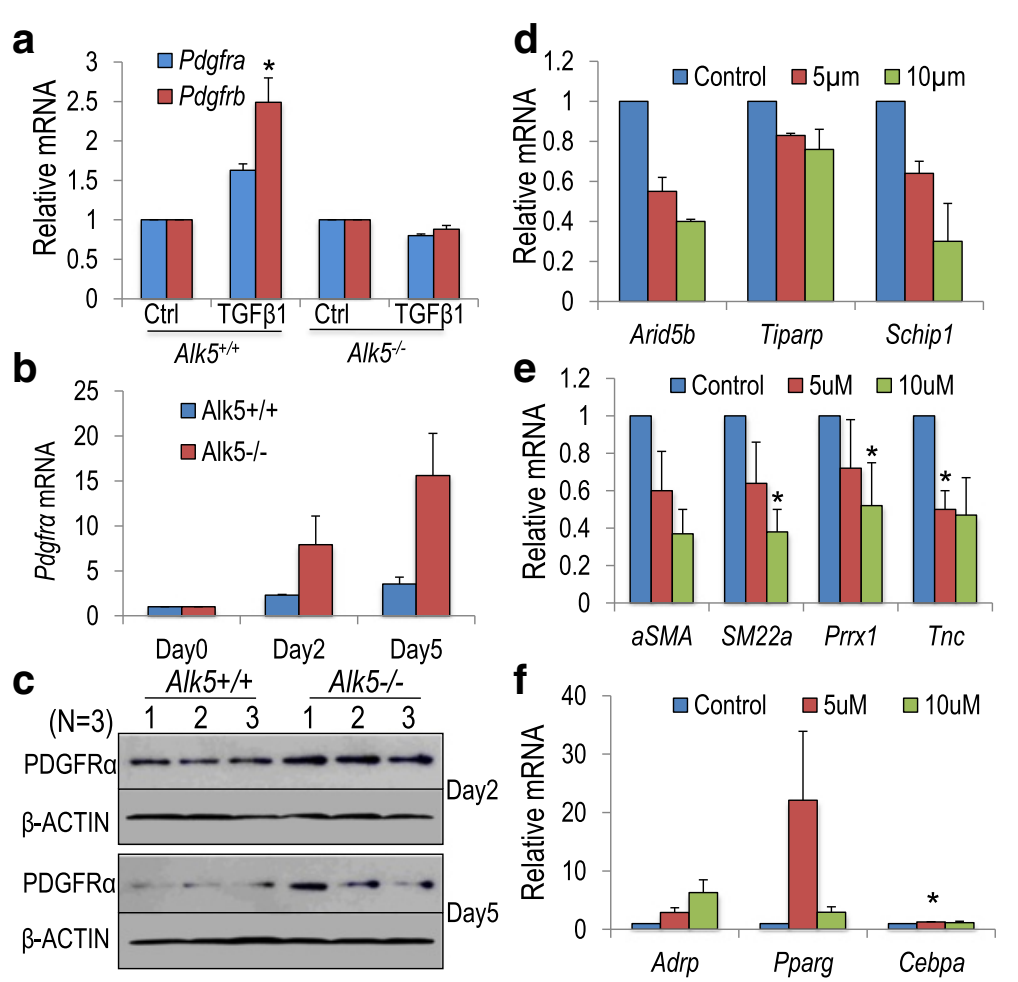

Fig. 6 Role of Pdgfra. (a) Quantitative PCR (Q-PCR) analysis showed induction (fold increase over controls) of Pdgfra and Pdgfr $\beta$ mRNAs in response to 48 hours of TGF $\beta 1$ treatment only in Alk5 $5^{+/+}$cells. Controls were treated exactly the same with the exception of bovine serum albumin in place of TGF $\beta$. For each condition, the RNA was isolated from combined triplicate wells. For Pdgfra, $n=2$ cell isolations from 6 pairs of lungs per experiment, repeated 2 to 3 times. For $P d g f r \beta, n=3$ cell isolations from 6 pairs of lungs per experiment. All conditions were initiated and analyzed after the same incubation period. (b) Progressive increase in Pdgfra and Pdgfr $\beta$ mRNAs, without TGF $\beta 1$-induction during spontaneous differentiation of Alk5 cell lines in culture for 0,2 , and 5 days. For each condition, the RNAs were isolated from combined triplicate wells. $n=2$ cell isolations from 6 pairs of lungs per experiment, repeated once for each. In both (a) and (b), RNA was isolated at the indicated time point and Q-PCR was performed immediately after. Note higher levels in $A / k 5^{-/-}$compared to Alk5 $5^{+/+}$cells on both day 2 and day 5. (c) Western blot analysis confirmed higher PDGFRa protein in three independent samples of $A / k 5^{-/-}$cells on both day 2 and day 5 , compared to $A / k 5^{+/+} . n=3$ independent experiments. $\beta$-ACTIN was used as a control. (d-f) $A / k 5^{+/+}$cells were treated with or without Imatinib at $5 \mu \mathrm{m}$ and $10 \mu \mathrm{m}$ for 5 days, mRNA for PDGF signaling target genes (d), myofibroblast-related genes (e) and lipofibroblast-related genes (f) were analyzed by Q-PCR ( $n=2$ cell isolations from 6 pairs of lungs per experiment for (d) and $n=3$ cell isolations from 6 pairs of lungs per experiment for (e) and (f). Error bars show standard deviation in (d) and standard error of the means in (e) and (f). ${ }^{*} P<0.05$

both day 2 and day 5 of culture (Fig. 6c). These observations suggest the possibility of alternative or additional mechanisms that may regulate PDGFR $\alpha$ expression in these cells.

The need for signaling through PDGFR $\alpha$ during $\alpha \mathrm{SMA}^{\text {pos }}$ cell differentiation was examined in vitro and in vivo. Application of the kinase inhibitor Imatinib to $A l k 5^{+/+}$cells reduced the mRNA for known PDGFA targets Arid5b, Tiparp, and Schip1 (Fig. 6d), thereby validating its use. Importantly, Imatinib reduced the expression of myogenic markers (Fig. 6e) but, of the LIF markers, only Ppary was strongly increased. Adrp was modestly increased by higher Imatinib doses (Fig. 6f). These results suggest that Pdgfra inactivation in mesodermal precursors prevents $\alpha \mathrm{SMA}^{\mathrm{pos}}$ cell differentiation but is insufficient to promote LIF commitment.
To confirm this finding in vivo, genetically engineered mice were generated in which Pdgfr $\alpha$ was inactivated in mesodermal tissues by Dermo1-cre. The resulting Pdgfra ${ }^{\text {flox/flox }}$;Dermo1-cre mice $\left(\right.$ Pdgfra $\left.{ }^{\text {Dermo1 }}\right)$ survived to birth at predicted Mendelian ratios but were $22 \%$ smaller than control littermates $(1.45 \pm 0.03 \mathrm{~g}$ vs. $1.14 \pm 0.04 \mathrm{~g}, P<0.001)$. Pdgfra ${ }^{\text {Dermo1 }}$ mutant mice also developed spina bifida as reported in mice deficient in PDGFR $\alpha$-stimulated phosphatidyl-inositol 3' kinase activity [23]. IHC on E18.5 control lungs localized PDGFR $\alpha$-expressing cells to the stroma and to areas surrounding the airways and blood vessels (Fig. 7a). These cells were absent or significantly reduced in Pdgfra${ }^{\text {Dermol }}$ lungs (Fig. 7b and Additional file 6). Q-PCR showed reduced mRNA for PDGFA targets, including Zfand5, Myole, Arid5b, Tiparp, and Schip1 [32], confirming functionally repressed PDGFA signaling in Pdgfra ${ }^{D e r m o 1}$ lungs 


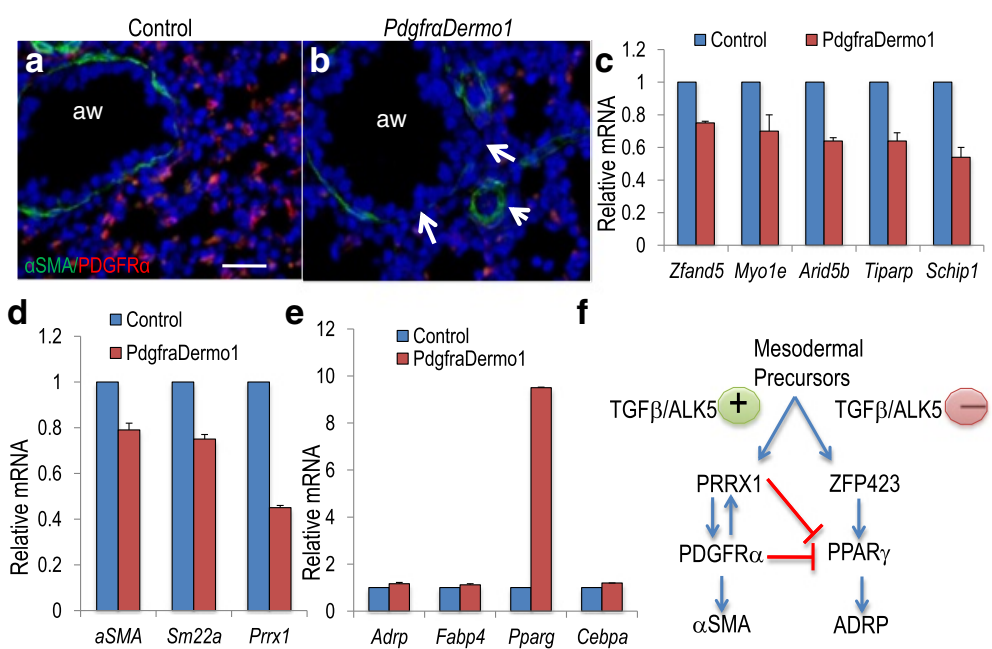

Fig. 7 Mesodermal progenitor-specific deletion of Pdgfra. (a and $\mathbf{b}$ ) Immunohistochemistry showed PDGFRa (red) is lost in the lung mesenchyme and aSMA (green) is decreased in E18.5 Pdgfra Dermol lungs. Arrows indicate gaps in aSMA in mutant lungs. "aw" indicates airway. (c) Quantitative PCR (Q-PCR) showed a decrease in mRNA for PDGF signaling target genes, indicating an overall functional repression of the signaling pathway in E18.5 Pdgfra ${ }^{\text {Dermol }}$ lungs. $n=2$ pairs of separate lungs, repeated once for each. (d) Q-PCR showed myofibroblast-related genes are decreased in E18.5 Pdgfra ${ }^{\text {Dermol }}$ lungs. $n=2$ pairs of separate lungs, repeated once. (e) Q-PCR showing only Ppary is robustly increased among lipofibroblastrelated genes in E18.5 Pdgfra ${ }^{\text {Dermol }}$ lungs. $n=2$ pairs of separate lungs, repeated once. (f) Schematic model for ALK5 binary switch function in mesodermal progenitor cell fate determination. TGF $\beta$ via ALK5 is a direct activator of Prrx1 (Fig. $5 f$ ) a key transcriptional regulator of the aSMA ${ }^{\text {pos }}$ cell pathway. TGF $\beta$ via ALK5 also directly stimulates Pdgfra mRNA (Fig. 6a), which further promotes aSMA ${ }^{\text {pos }}$ cell commitment [22]. PRRX1 and PDGFRa are reciprocal activators. In the absence of Alk5, Zfp423, which is normally repressed by TGF $\beta$ (Fig. 5I) is de-repressed, leading to activation of Ppary [28], a transcriptional activator of lipogenic cell commitment. PRRX1 and PDGFRa inhibit adipogenesis by directly repressing PPARY [44]. Error bars show standard error of the mean. Scale bar: $b=20 \mu \mathrm{m}$

(Fig. 7c and Additional file 7A). The $\alpha \mathrm{SMA}^{\text {pos }}$ cell layers in mutant lungs were reproducibly thinner compared to controls, with gaps in $\alpha$ SMA expression (Fig. 7b, Arrows and Additional file 6). Q-PCR of E18.5 Pdgfra ${ }^{\text {Dermo1 }}$ lungs showed decreased mRNA for multiple myofibroblast markers, including Prrx1 (0.45 \pm 0.01 of control), SM22 $\alpha$ $(0.75 \pm 0.02)$, and $\alpha S M A(0.79 \pm 0.03)$ (Fig. $7 \mathrm{~d})$. Myofibroblast marker mRNAs were similarly decreased in E14.5 Pdgfra ${ }^{\text {Dermo1 }}$ lungs (Additional file 7B). Similar analysis of adipogenic-related genes in Pdgfra ${ }^{\text {Dermo1 }}$ lungs at E18.5 showed increased Ppary mRNA but only modest increases in Adrp, Fabp4, and Cebpa (Fig. 7e). The balance between $\alpha \mathrm{SMA}^{\mathrm{pos}}$ cells and LIF phenotypes in Pdgfra ${ }^{\text {Dermo1 }}$ lungs was less severely distorted than those in $A l k 5^{D e r m o 1}$ mice. In sum, these data support a model whereby ALK5mediated TGF $\beta$ signaling regulates $\alpha \mathrm{SMA}^{\text {pos }}$ versus LIF cell differentiation only partly through the PDGFA/ PDGFR $\alpha$ pathway and that inhibition of this pathway is insufficient to promote LIF differentiation.

\section{Discussion and conclusions}

The present study provides genetic, histologic, and molecular evidence that mesodermal inactivation of $A l k 5$ in the mouse lung restricts $\alpha S M A^{\text {pos }}$ cell fate and promotes LIF differentiation. In this context, ALK5 meets the definition of a molecular binary switch that functions in determination and subsequent specialization of at least two key lung mesodermal cell lineages.

An early morphological phenotype of Alk5 $5^{\text {Dermol }}$ embryonic lungs is the reduced physical size of the SMM. This was associated with decreased proliferation of the lung mesoderm and reduction in Fgf9. Fgf9 is expressed by both the mesothelium and the epithelial layers in the lung $[1,2]$. Dermo1-cre is not known to be active in the mesothelium, although the origin of some mesothelial cells may be traced to the pulmonary mesoderm [33]. Whether reduced $F g f 9$ is due to direct impact of $A l k 5$ inactivation or a result of mesoderm-mesothelial cross communication remains unknown. FGF9 signaling through FGFR1 and FGFR2 is both necessary and sufficient for SMM growth. Although Alk5 inactivation modestly decreased Fgf9, PITX2, a homeodomain transcription factor that is induced by FGF9, was strongly inhibited (Fig. 1k). SMM volume is profoundly sensitive to FGF9 signaling, being entirely absent from $\mathrm{Fg} \mathrm{fg}^{-/}$ lungs and enlarged in Fgf9 gain-of-function mutants [1]. The reduced SMM size and mitotic index indicate that ALK5 is required for either mesothelial Fgf9 expression or FGF9 responsiveness. Ligand-dependent TßRII signaling has been shown to regulate FGF9- and PITX2mediated cell proliferation in the palatal mesenchyme [34]. Our observations suggest that ALK5 may similarly 
mediate TGF $\beta$-mediated control of FGF9 signaling within the SMM.

The Alk5 $5^{\text {Dermol }}$ lungs also displayed defective epithelial differentiation. As Dermo1 is exclusively mesodermal, the abnormalities in epithelial cell differentiation presumably represent altered mesenchymal regulation of epithelial progenitors. Previous studies have suggested that FGF7, which is reduced in Alk5 $5^{\text {Dermol }}$ lungs, participates in mesenchymal-epithelial cross-talk [2]. Alternatively, TGF $\beta$ also regulates epithelial differentiation by altering the composition of the underlying matrix [35]. Finally, TUNEL ${ }^{\text {pos }}$ cells were found scattered in the parenchyma of late stage (i.e. E18.5) Alk5 $5^{\text {Dermo1 }}$ lungs (Additional file 8). Although these cells are not localized to the airways, the possibility that some of the changes in airway gene expression may be due to increased apoptosis cannot be presently ruled out.

The loss of Alk5 in mesodermal progenitors also disrupted pulmonary vasculogenesis. Flk1, also known as vascular endothelial growth factor receptor 2, is expressed by endothelial progenitors [36] and was strongly decreased in E13.5 Alk5 $5^{\text {Dermo1 }}$ lungs. This likely accounts for the simplified vasculature observed in E18.5 mutant lungs. Since Dermo1 may not be expressed in endothelial progenitors $[37,38]$, it is unclear whether Alk5 directly participates in vascular endothelial cell commitment. In addition, reduced $F g f 9$ in $A l k 5^{\text {Dermo } 1}$ lungs might also contribute to the observed vascular phenotype. Increased $F g f 9$ in vivo is sufficient to expand the network of Tie2-lacZ and PECAM ${ }^{\text {pos }}$ cells through stimulation of undifferentiated mesenchyme and/or vascular progenitor cells [1].

The key finding of the present study is that inactivation of Alk5 inhibits $\alpha \mathrm{SMA}^{\mathrm{pos}}$ and promotes LIF differentiation, both in vivo and in cultured lung mesodermal cell lines. Markers of myofibroblast differentiation, including $\alpha$ SMA, SM22 $\alpha$, and calponin, were reduced, while mediators of lipogenic commitment, such as ADRP, were robustly increased. The mechanism underlying this phenotype is complex. Since TGF $\beta$ signaling is known to induce $\alpha \mathrm{SMA}^{\text {pos }}$ cell differentiation, its inhibition is readily explicable by ALK5 deficiency. In addition, FGF10 ${ }^{\text {pos }}$ cells are known to contribute to $\alpha_{S M A}{ }^{\text {pos }}$ cells during lung development [3]. FGF10 mRNA was reduced as was the physical size of SMM, the site of FGF $10^{\text {pos }}$ cells. In contrast to this finding, we had previously found increased Fgf10 mRNA and SHH signaling in mesodermally-targeted $T \beta R 2^{\text {Dermol }}$ lungs [39]. The discrepancy between the previous and present observations on FGF10 provides an excellent illustration of differential TGF $\beta$ signaling via receptor selectivity as described in the Background section. Thus, receptor selectivity (TRR2 vs. ALK5) represents an important mechanism by which TGF $\beta$ can impose a vast spectrum of physiologic changes on different (or same) tissues and cell types. In the present study, when the observation on reduced Fgf10 levels in the Alk $5^{\text {Dermol }}$ lungs is combined with a diminished mitotic cell index in the SMM compartment, the data suggest a decreased number of FGF $10^{\text {pos }}$ cells and hence reduced $\alpha \mathrm{SMA}^{\mathrm{pos}}$ cell differentiation. Consistent with this conclusion, histological analysis of Alk5 $5^{\text {Dermo1 }}$ lungs revealed reduced $\alpha \mathrm{SMA}^{\text {pos }}$ cell differentiation in the PBSM but not in perivascular smooth muscle cells (Fig. 2f). It is unclear whether PBSM cells and vascular smooth muscle cells have common or distinct developmental origins.

PDGFR $\alpha$ is also expressed by $\alpha \mathrm{SMA}^{\text {pos }}$ progenitors and was similarly and profoundly reduced in Alk $5^{\text {Dermo } 1}$ lungs. Its functional abrogation was confirmed by reduced phosphorylation of AKT, its principle intracellular substrate (Fig. 3). Our study showed that the TGF $\beta$ ALK5 axis regulates $P d g f r \alpha$ mRNA expression (Fig. 6a). Therefore, it was surprising to find that Pdgfra mRNA increased during spontaneous differentiation of $A l k 5^{-/-}$ cells to LIFs (Fig. 6b). It is likely that in these isolated cells alternative or additional mechanisms may exist which regulate Pdgfra expression, independent of the TGF $\beta$-ALK5 axis. One potential mechanism may be increased spontaneous phosphorylation of ERK found in Alk $5^{-/-}$cells compared to $A l k 5^{+/+}$cells and $A l k 5^{\text {Dermo } 1}$ lungs (Figs. 4 and 5). The underlying cause of increased p-ERK in cells lacking ALK5 activity is outside the scope of the present study, but is being currently investigated in separate studies. What remains firmly established from these in vitro studies is that inhibition of PDGFR $\alpha$ by Imatinib reduced expression of myofibroblast markers but did not fully promote LIF differentiation; of the lipogenic genes, only Ppary was increased. This finding was validated by genetic targeting of $P d g f r \alpha$ in vivo (Fig. 7). Inactivation of Pdgfra in early mesodermal progenitors $\left(P d g f r a^{D e r m o 1}\right)$ robustly inhibited the expression of myofibroblast-specific genes (Fig. 7d), while, compared to Alk5 $5^{\text {Dermo1 }}$ lungs, the impact on LIF differentiation was subtle, despite strong activation of Ppary in cultured cells. Thus, while PDGFR $\alpha$ is required for full expression of the myofibroblast-specific gene battery, its absence is capable of initiating, but not completing, the LIF differentiation program.

LIFs are critical regulators of alveologenesis and assimilate and transfer neutral lipids to adjacent type II cells, thereby facilitating surfactant formation [40]. LIF commitment may be favored by increased expression of PTEN, a phosphatase that regulates the fate of mesodermal progenitors (Fig. 4f). This finding recapitulates our previous study in which Dermo1-cre-mediated inactivation of Pten profoundly reduced ADRP [14]. Pten was originally identified as a negatively regulated target of TGF $\beta$ signaling [41]. 
Based on the collective observations in this study we propose a model whereby multiple signaling pathways, controlled by ALK5-mediated TGF $\beta$ signaling, converge on transcriptional factors that regulate the cell lineage determination of two key mesodermal specialized cell types (Fig. 7f). The two major transcription factor targets of this process include the adipogenic zinc finger transcription factor ZFP423, and the myogenic transcription factor PRRX1. Activation of $Z f p 423$ through knockdown of Zfp521, its negative regulator, is capable of altering mesodermal cell fate from osteogenic to lipogenic lineage [42]. We found increased LIFs in Alk $5^{\text {Dermo1 }}$ lungs associated with increased Zfp 423 mRNA. Likewise, $Z f p 423$ increased robustly in cultured Alk $5^{-/-}$cells undergoing spontaneous LIF differentiation (Fig. 5j). Importantly, TGF $\beta 1$ strongly repressed Zfp 423 , and only in presence of functional ALK5 (Fig. 5l). Thus, while ALK5 activity is required for $\alpha \mathrm{SMA}^{\text {pos }}$ cell lineage commitment, its inactivation de-represses Zfp 423 favoring early LIF lineage commitment. In support of this conclusion, we found profoundly increased expression of Wisp2, known to be expressed at high levels in committed adipocyte precursors. In contrast, PRRX1 is a mesodermal transcription factor [43] that promotes differentiation of mesenchymal precursors into $\alpha \mathrm{SMA}^{\mathrm{pos}}$ cells. PRRX1 inhibits adipogenesis while its stable knockdown enhances adipogenesis, as shown by increased Ppary, Cebpo, and Fabp4 expression [44]. In Alk $5^{\text {Dermo1 }}$ lungs, Prrx 1 decreased as Zfp 423 increased, indicating a key mechanism by which $A l k 5$ repression facilitates LIF commitment while inhibiting $\alpha \mathrm{SMA}^{\text {pos }}$ cell differentiation.

In conclusion, these data establish that ALK5 has a regulatory role in the control of early mesodermal progenitor commitment between two alternative cell lineages. This role is consistent with previous in vitro studies wherein genome-wide pathway analysis identified members of the TGF $\beta$ superfamily as modulators of adipocyte/myocyte differentiation [45]. $\alpha \mathrm{SMA}^{\mathrm{pos}}$ cell determination is regulated by TGF $\beta$ signaling and requires further signaling by FGF9 and PDGFR $\alpha$. In the wild type multipotential mesoderm, activation of the $\alpha \mathrm{SMA}^{\text {pos }}$ cell pathway, mediated by the transcription factor PRRX1 also limits the ontogeny of LIFs. Blocking ALK5mediated TGF $\beta$ signaling in ALK5 $5^{\text {Dermo1 }}$ mesoderm inhibited $\alpha \mathrm{SMA}^{\text {pos }}$ cell differentiation and increased (de-repressed) the expression of Zfp 423 , the key LIF transcription factor [28]. Therefore, it appears that, while $\alpha \mathrm{SMA}^{\text {pos }}$ cell lineage is actively determined by ALK5-mediated TGF $\beta$ signaling, LIF determination represents a default position on a biological binary switch. This means that LIF can be activated only when $\alpha \mathrm{SMA}^{\mathrm{pos}}$-promoting stimuli are diminished or eliminated.

\section{Methods}

\section{Animals}

The Alk5 $5^{\text {flox flox }}$ (C57BL6 background) and Dermo1-cre mice were described previously $[39,46]$. Pdgfraflox/flox mice were purchased from the Jackson Laboratory. Mesodermal progenitor specific knockout mutants,

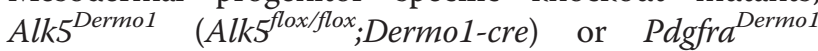
(Pdgfraflox/flox; Dermo1-cre) were generated by crossing Alk5 $5^{\text {flox/flox }}$ or Pdgfraflox/flox homozygous females with Alk $5^{\text {flox/+ }}$;Dermo1-cre or Pdgfra ${ }^{\text {flox/+ }}$;Dermo1-cre double heterozygous males in a pure C57BL6 background. Alk $5^{f l o x}$ flox or Pdgfra ${ }^{\text {floxfllox }}$ mice were used as control. Triple transgenic Alk $5^{\text {flox/flox }}$;Dermo1-cre; $\operatorname{TTmG}$ mice (simply Alk5 $5^{\text {Dermol }} ; m \operatorname{Tm} G$ ) were generated as previously reported [47]. Genotyping of the Dermo1-cre mice containing $A l k 5^{f l o x}, A l k 5^{\Delta}$, and $A l k 5^{w t}$ alleles was as previously described [39, 46]. All animal procedures were performed according to approved University of Southern California Institutional Animal Care and Use Committee regulations.

\section{Tissue collection and Oil Red $O$ staining}

Embryonic lungs from control and mutant lungs were collected at various embryonic stages from E11.5 to E18.5. The embryos or lungs were dissected and fixed overnight in $4 \%$ paraformaldehyde at $4{ }^{\circ} \mathrm{C}$. They were then dehydrated through increasing ethanol concentration and embedded in paraffin or OCT compound. Sections of $5-\mu \mathrm{m}$ thickness were used for histological analysis. Frozen lung sections or cultured cells were stained with Oil Red O to detect LIFs according to the manufacturer's protocol (Poly Scientific, Bayshore, NY, USA). The experiments were repeated using three mice within each genotype group $(n=3)$. For raw data pertaining to quantification of Oil Red $\mathrm{O}$ positive cells in Additional file 5, please see Additional file 9.

\section{TUNEL assay}

Apoptotic cells were detected by using TUNEL detection kit (In Situ Cell Death Detection Kit, Roche Diagnostics, Indianapolis, IN, USA). Briefly, tissue sections were deparaffinized, rehydrated, and washed with distilleddeionized water. After treatment with proteinase $\mathrm{K}$ (Invitrogen, Carlsbad, CA, USA), fragmented DNA was labeled with fluorescein-dUTP, using terminal transferase (Roche Diagnostics). Slides were mounted with VECTASHIELD containing DAPI (Vector Laboratories, Burlingame, CA, USA). The apoptotic percentage was obtained as previously described [12] by manual counting of TUNEL ${ }^{\text {pos }}$ cells in groups of 4,000 or more cells.

\section{Immunohistochemistry (IHC)}

Routinely prepared histological sections were deparaffinized with xylene and rehydrated through an alcohol 
gradient series to water. Antigens were retrieved and endogenous peroxidase activity was quenched using $3 \%$ hydrogen peroxide. After normal serum blocking, the sections were incubated with a primary antibody at $4{ }^{\circ} \mathrm{C}$ overnight. Impress-anti-rabbit or anti-mouse or antigoat IgG (Vector Laboratories) were applied for $50 \mathrm{~min}$ at room temperature. Staining was visualized by Peroxidase Substrate Kit DAB (Vector Laboratories). For immunofluorescence staining, the sections were incubated with primary antibodies overnight at $4{ }^{\circ} \mathrm{C}$. After washing steps, the sections were reacted with a mixture of DyLight ${ }^{\mathrm{m}} 549$-conjugated donkey anti-rabbit or antimouse IgG $(\mathrm{H}+\mathrm{L})$ or DyLight ${ }^{\mathrm{m}} 488$-conjugated donkey anti-mouse IgG or anti-goat IgG $(\mathrm{H}+\mathrm{L}$ ) (all from Jackson ImmunoResearch Laboratories, Inc., West Grove, PA, USA) for $1 \mathrm{~h}$ in the dark at room temperature. After thorough rinses with PBS containing $0.1 \%$ Triton X-100, the sections were mounted with VECTASHIELD mounting medium containing DAPI (to visualize nuclei). Primary antibodies used are described in Additional file 10. The experiments were repeated in more than three mice within each genotype group $(n>3)$.

\section{Mesenchymal cell isolation, SV40 transformation, Fluorescence Activated Cell Sorting (FACS) and treatment} Primary mesenchymal cells were isolated by differential adherence [48]. Briefly, fetuses were dissected from pregnant control and mutant mice at E15.5 or E16.5. Six pairs of lungs were pooled for each experiment $(n=6)$. Lungs were dissociated with $0.025 \%$ trypsin/EDTA in DMEM (Gibco) at $37{ }^{\circ} \mathrm{C}$. The cells were filtered and plated in $75 \mathrm{~cm}^{2}$ tissue culture flasks for $1 \mathrm{~h}$, after which the non-adherent cells were discarded. Adherent cells were then washed and grown for $24 \mathrm{~h}$. The primary cells were subsequently transformed by SV40 infection and subjected to FACS based on GFP activity using ArialI (Becton Dickinson). Gates were set according to unstained controls. After FACS, GFP ${ }^{\text {pos }}$ cells were either plated on 6-well plates in DMEM, containing $10 \%$ fetal bovine serum, FBS (Gibco) for subsequent analysis, or directly subjected to Q-PCR.

For TGF $\beta 1$ (R\&D Systems, Minneapolis, MN, USA) or Imatinib (Cayman Chemical Co. Ann Arbor, MI, USA) treatment, the purified $A l k 5^{+/+}$or $A l k 5^{-/-}$cells were plated at a density of $5 \times 10^{4}$ cells $/ \mathrm{cm}^{2}$ into 6 -well tissue culture plates in DMEM with $10 \%$ FBS. Cells were serum-starved overnight before treatment with TGF $\beta 1$ (4 ng/mL according to the manufacturer's recommendation) or imatinib (5 $\mu \mathrm{L}$ and $10 \mu \mathrm{L})$. TGF $\beta$ treatment was for $48 \mathrm{~h}$; Imatinib treatment was for 5 days. Controls were treated exactly the same with the exception of BSA in place of TGF $\beta$ and DMSO in place of Imatinib. All conditions in Fig. 6a (Control, Alk $5+/+$, Alk $5^{-/-}$) were initiated and analyzed after the same incubation period.
For adipogenesis differentiation, low-passage $(<6$ passages) $A l k 5^{+/+}$and $A l k 5^{-/-}$cells were plated at a density of $5 \times 10^{4}$ cells $/ \mathrm{cm}^{2}$ in DMEM containing $10 \%$ FBS. At $80 \%$ confluence, old medium was aspirated and replaced with fresh DMEM containing $2 \%$ FBS. After 2, 5, or 10 days of incubation, the cells were stained with Oil Red $\mathrm{O}$ according to the manufacturer's protocol (Poly Scientific, Bayshore, NY, USA) or prepared for RNA and protein analysis. Alk $5^{+/+}$ and $A l k 5^{-1-}$ cells at $80 \%$ confluence were used as a control. All experiments were performed in duplicate three times $(n=3)$.

\section{Western blot analysis}

Total protein was extracted with RIPA buffer (Sigma, St. Louis, MO, USA) from embryonic lung tissues or cultured cells. Protein concentrations were determined by a BCA Protein Assay kit (Thermo Scientific, Grand Island, NY, USA); $15-30 \mu \mathrm{g}$ of protein was loaded onto 3-8 \% NuPAGE gels and transferred to Immobilon-P membranes (both from Millipore Corp, Billerica, MA, USA). Membranes were then blocked with $5 \%$ milk in Trisbuffered saline and incubated with primary antibodies overnight. The secondary antibodies, goat-anti-rabbit or goat-anti-mouse IgG-HRP (both from Pierce, Thermo Scientific), were applied at a 1:1000 dilution for $30 \mathrm{~min}$. Membranes were reacted with chemiluminescence reagent ECL (Amersham Biosciences, GE Healthcare Life Sciences, PA, USA) and exposed to photographic film (Amersham Hyperfilm ECL). The primary antibodies used are described in Additional file 10.

\section{Quantitative Polymerase Chain Reaction (Q-PCR)}

DNase-free RNA was prepared using Trizol reagent (Invitrogen) according to the manufacturer's instructions. After DNase treatment, total RNA $(2 \mu \mathrm{g})$ was reverse-transcribed to cDNA using the Superscript III First-Strand Synthesis System for RT-PCR kit (Invitrogen), according to the manufacturer's instructions. The cDNA was subjected to Q-PCR using SYBR Green PCR Master Mix with a LightCycler (Roche) as previously described [47]. Gene expression was normalized to $\beta$-actin or Tbp. All primers for Q-PCR were designed by using the program of Universal Probe Library Assay Design Center from Roche Applied Sciences. Specificity of each PCR reaction was verified by electrophoresis on $2 \%$ gel.

Relative quantification analysis was carried out with LightCycler software, Version 4 (Roche). The results were expressed as a normalized ratio (fold). $\beta$-actin or Tbp were used as reference genes for normalization. Samples from control lungs served as 'Calibrators'. For raw data pertaining to Q-PCR studies, please see Additional file 9. 


\section{Statistical analysis}

In total, the lungs or embryos from 98-pair Alk5 $5^{\text {Dermo1 }}$ mutant and control mice were analyzed using different techniques. For Q-PCR and western blot analysis, most experiments were performed two or three times, and the samples in each experiment were analyzed in triplicates or duplicates. All data are represented as mean \pm standard error or standard error of the mean. The significance of differences between two sample means was determined by the two-tailed Student $t$-test, which is a common and well established statistical method to ascertain differences between two samples. Level of significance was denoted by $P<0.05$.

\section{Availability of supporting data}

Data supporting the results of this article are available in Additional file 9 .

\section{Additional files}

Additional file 1: Dermo1-cre-mediated mesodermal progenitor-specific deletion of Alk5. A-C. Dermo 1-cre expression pattern in E14.5 Dermo 1cre:mTmG lungs. Dermo 1-cre-mediated recombination (green fluorescence) was located in the mesenchyme surrounding the trachea (A), bronchi (B), bronchioles and blood vessels (C), not in the epithelial cells. D. Deletion of Alk5 exon 3 by crossing Alk5 flox/lox to Dermo1-cre mice. E. Deletion of Alk5 was validated by $P C R$ with genomic DNA. F. Western blot analysis using total protein from E16.5 control and Alk $5^{\text {Dermo } 1}$ lungs. $n=3$. $\beta$-ACTIN was used as a control. G-J. Immunohistochemistry for ALK5 (G and I) and PAl-1 ( $\mathrm{H}$ and $\mathrm{J}$ ) showed lost or decreased ALK5 and PAl-1 (Arrows in I and J) in

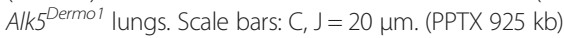

Additional file 2: Mesodermal-specific Alk5 inactivation causes pulmonary hypoplasia. A-D. Gross morphology of E16.5 control (A and B) and Alk5 $5^{\text {Dermol }}$ (C and D) lungs. E-J. PAS (E, H, G and J) and H\&E (F and I) staining of E18.5 control (E-G) and $A / k 5^{\text {Dermol }}(\mathrm{H}-J)$ lungs. Arrows in I indicate a thicker alveolar wall in Alk5 ${ }^{\text {Dermol }}$ lungs; Arrows in $J$ indicate robust PAS

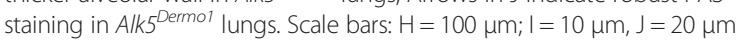
(PPTX $1736 \mathrm{~kb})$

Additional file 3: Mesodermal Alk5 deficiency inhibits epithelial cell differentiation and disrupts vasculogenesis. A-H. Immunohistochemistry (IHC) for Acetylated-tubulin (A and E), CC10 (B and F), pro-SPC (C and G) and T1a $(\mathrm{D}$ and $\mathrm{H})$ in E18.5 control and Alk5 ${ }^{\text {Dermol }}$ lungs showing decreased expression of the latter genes in Alk5 $5^{\text {Dermol }}$ lungs. I. Q-PCR confirmed inhibition of epithelial cell markers in Alk $5^{D e r m o l}$ lungs, $n=2-9$ pairs of separate lungs. J and L: IHC for GFP and FLK1 showing decreased $\mathrm{GFP}^{+} / \mathrm{FLK} 1^{+}$cells in E14.5 Alk5 $5^{\text {Dermol }}$ lungs. $\mathrm{K}$ and $\mathrm{M}$ : $\mathrm{IHC}$ showed decreased $\mathrm{CD}_{4}{ }^{+}$cells in E14.5 Alk5 $5^{\text {Dermol }}$ lungs. N-Q. IHC showing decreased of

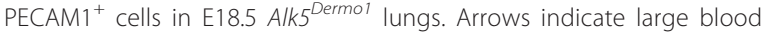
vessels appearing intact. R. Quantitative PCR confirmed decreased Pecam1, Flk1, and Flt1 mRNAs in E13.5 mutant lungs. $n=3$ pairs of separate lungs. Error bars show standard deviation. ${ }^{*} P<0.05$. Scale bars: $\mathrm{H}=30 \mu \mathrm{m} ; \mathrm{M}$ and $\mathrm{Q}=20 \mu \mathrm{m}$. (PPTX $1560 \mathrm{~kb}$ )

Additional file 4: Quantification of sub-mesothelial mesenchyme (SMM) size. Hematoxylin and eosin-stained lung tissue sections were prepared and random images were collected under 40x objective from both control and Alk5 $5^{\text {Dermol }}$ embryos at E12.5 and E13.5. The various dimensions that were measured included boundaries of the SMM compartments, as delineated on each photomicrograph, from mesothelium to the mesenchyme wrapped around the epithelium (SEM). The regions encompassing the SMM were measured in Photoshop by dividing each region at random of six points to manually calculate the length from mesothelium to SEM ( $\mu \mathrm{m})$. Sample size, $n=3$ separate lung tissue sections. Error bars show standard deviation. ${ }^{*} P<0.05$. (PPTX $75 \mathrm{~kb}$ )
Additional file 5: Quantification of Oil Red O storage. Lung tissue sections from E18.5 control and Alk5 $5^{\text {Dermol }}$ lungs were analyzed by staining with Oil Red O for assessment of LIF differentiation. Oil Red O stained sections were viewed and random images were collected under $40 \times$ objective, and were analyzed by imaging using a previously described protocol [49], $n=3$. The density of Oil Red O stained cells was then calculated and plotted as shown. Error bars show the standard deviation. ${ }^{*} P<0.05$ (PPTX $43 \mathrm{~kb}$ )

Additional file 6: Quantification of smooth muscle (SM) thickness and areas covered by smooth muscle in control and Pdgfra ${ }^{\text {Dermol }}$ lungs at E18.5. aSMA immunohistochemical stained lung sections were collected by random sampling using the $40 \times$ objective from three pairs of control and Pdgfra ${ }^{D e r m o l}$ mutant lungs at E18.5. The thickness and coverage of SM were quantified. A. Quantification of SM thickness. The arithmetic mean thickness of the SM cell layer was determined by volume of aSMA $^{\text {pos }}$ compartment, measured by counting all points intercepting the airway epithelium and aSMA ${ }^{\text {pos }}$ compartment. $n=3$. B. Quantification of SM coverage. The percentage of SM airway coverage was determined by assessing the percentage of the airway epithelium circumference in contact with number of aSMA ${ }^{\text {pos }}$ cells. $n=3$. Error bars show the standard deviation. ${ }^{*} P<0.05$ (PPTX $54 \mathrm{~kb}$ )

Additional file 7: Mesodermal progenitor-specific deletion of Pdgfra. A. Quantitative PCR (Q-PCR) showed PDGF signaling target genes are decreased, indicating an overall functional repression of PDGFA signaling

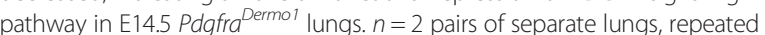
twice or thrice. B. Q-PCR showed repression of myofibroblast-related genes

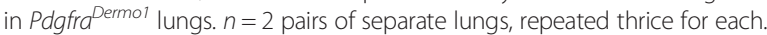
Error bars show SEM. (PPTX $68 \mathrm{~kb}$ )

Additional file 8: Mesodermal Alk5 deficiency increased cell apoptosis. The number of TUNEL ${ }^{\text {pos }}$ cells as determined by previously described methods [12]. A-D. TUNEL assay showed increased number of TUNEL ${ }^{\text {pos }}$ cells in the Alk5 $5^{\text {Dermol }}$ lungs at E18.5. E. Quantification of the relative number of TUNEL ${ }^{\text {pos }}$ cells (green) per 4,000 total cells. Error bars show standard deviation. ${ }^{*} P<0.05$. (PPTX $794 \mathrm{~kb}$ )

Additional file 9: Raw data. (XLSX 247 kb)

Additional file 10: Primary antibodies used in western blots and immunohistochemistry. (DOC $37 \mathrm{~kb}$ )

\section{Abbreviations}

FACS: Fluorescence Activated Cell Sorting; IHC: Immunohistochemistry; LIF: Lipofibroblasts; PBSM: Peribronchial smooth muscle; Q-PCR: Quantitative polymerase chain reaction; SM: Smooth muscle; SMM: Sub-mesothelial mesenchyme; TGF $\beta$ : Transforming growth factor beta.

\section{Competing interests}

The authors declare that they have no competing interests.

\section{Authors' contributions}

AL and PM conceived the study and designed the experiments. AL, SM, SMS, and $A F$ performed the experiments. $A L, P M, C L$, and $S B$ analyzed data. $A L$ and PM wrote the manuscript. MKL, ZB, CL, and SB discussed the results and commented on the manuscript. All authors read and approved the final manuscript.

\section{Acknowledgements}

This work was supported by NIH/NHLBI and generous funds from the Hastings Foundation. Parviz Minoo is Hastings Professor of Pediatrics.

\section{Author details}

'Division of Newborn Medicine, Department of Pediatrics, LAC+USC Medical Center and Childrens Hospital Los Angeles, Keck School of Medicine of USC, Los Angeles, CA 90033, USA. ${ }^{2}$ Will Rogers Institute Pulmonary Research Center, Division of Pulmonary, Critical Care and Sleep Medicine, Department of Medicine, Keck School of Medicine of USC, Los Angeles, CA 90033, USA. ${ }^{3}$ Hastings Center for Pulmonary Research, Keck School of Medicine of USC, Los Angeles, CA 90033, USA. " Excellence Cluster Cardio Pulmonary System, University Justus Liebig Giessen, Giessen 39352, Germany. ${ }^{5}$ Institute of Fundamental Medicine and Biology, Kazan Federal University, Kremlevskaya St 18, Kazan 420008, Russia. 


\section{Received: 14 October 2015 Accepted: 26 February 2016} Published online: 16 March 2016

\section{References}

1. White AC, Xu J, Yin Y, Smith C, Schmid G, Ornitz DM. FGF9 and SHH signaling coordinate lung growth and development through regulation of distinct mesenchymal domains. Development. 2006;133(8):1507-17.

2. El Agha E, Herold S, Al Alam D, Quantius J, MacKenzie B, Carraro G, et al. Fgf10-positive cells represent a progenitor cell population during lung development and postnatally. Development. 2014;141(2):296-306.

3. Mailleux AA, Kelly R, Veltmaat JM, De Langhe SP, Zaffran S, Thiery JP, et al. Fgf10 expression identifies parabronchial smooth muscle cell progenitors and is required for their entry into the smooth muscle cell lineage. Development. 2005;132(9):2157-66.

4. Minoo P, King RJ. Epithelial-mesenchymal interactions in lung development. Annu Rev Physiol. 1994;56:13-45

5. Cardoso WV, Lu J. Regulation of early lung morphogenesis: questions, facts and controversies. Development. 2006;133(9):1611-24.

6. Shannon JM, Hyatt BA. Epithelial-mesenchymal interactions in the developing lung. Annu Rev Physiol. 2004;66:625-45.

7. Sakaki-Yumoto M, Katsuno Y, Derynck R. TGF-beta family signaling in stem cells. Biochim Biophys Acta. 2013;1830(2):2280-96.

8. Feng $\mathrm{XH}$, Derynck R. Specificity and versatility in tgf-beta signaling through Smads. Annu Rev Cell Dev Biol. 2005:21:659-93.

9. Bachman KE, Park BH. Duel nature of TGF-beta signaling: tumor suppressor vs. tumor promoter. Curr Opin Oncol. 2005;17(1):49-54

10. Larsson J, Goumans MJ, Sjostrand LJ, van Rooijen MA, Ward D, Leveen P, et al. Abnormal angiogenesis but intact hematopoietic potential in TGF-beta type I receptor-deficient mice. EMBO J. 2001;20(7):1663-73.

11. Oshima M, Oshima H, Taketo MM. TGF-beta receptor type II deficiency results in defects of yolk sac hematopoiesis and vasculogenesis. Dev Biol. 1996;179(1):297-302

12. Li M, Krishnaveni MS, Li C, Zhou B, Xing Y, Banfalvi A, et al. Epitheliumspecific deletion of TGF-beta receptor type II protects mice from bleomycininduced pulmonary fibrosis. J Clin Invest. 2011:121(1):277-87.

13. Sureshbabu A, Syed MA, Boddupalli CS, Dhodapkar MV, Homer RJ, Minoo P, et al. Conditional overexpression of TGFbeta1 promotes pulmonary inflammation, apoptosis and mortality via TGFbetaR2 in the developing mouse lung. Respir Res. 2015:16:4.

14. Tiozzo C, Carraro G, Al Alam D, Baptista S, Danopoulos S, Li A, et al. Mesodermal Pten inactivation leads to alveolar capillary dysplasia-like phenotype. J Clin Invest. 2013:122(11):3862-72.

15. White AC, Lavine KJ, Ornitz DM. FGF9 and SHH regulate mesenchymal Vegfa expression and development of the pulmonary capillary network Development. 2007;134(20):3743-52.

16. Matsunobu $T$, Torigoe $K$, Ishikawa $M$, de Vega $S$, Kulkarni $A B$, Iwamoto $Y$, et al. Critical roles of the TGF-beta type I receptor ALK5 in perichondrial formation and function, cartilage integrity, and osteoblast differentiation during growth plate development. Dev Biol. 2009;332(2):325-38.

17. Klinger S, Turgeon B, Levesque K, Wood GA, Aagaard-Tillery KM, Meloche S. Loss of Erk3 function in mice leads to intrauterine growth restriction, pulmonary immaturity, and neonatal lethality. Proc Natl Acad Sci U S A. 2009;106(39):16710-5.

18. Ramasamy SK, Mailleux AA, Gupte W, Mata F, Sala FG, Veltmaat JM, et al Fgf10 dosage is critical for the amplification of epithelial cell progenitors and for the formation of multiple mesenchymal lineages during lung development. Dev Biol. 2007;307(2):237-47.

19. Weaver M, Batts L, Hogan BL. Tissue interactions pattern the mesenchyme of the embryonic mouse lung. Dev Biol. 2003:258(1):169-84.

20. Yi L, Domyan ET, Lewandoski M, Sun X. Fibroblast growth factor 9 signaling inhibits airway smooth muscle differentiation in mouse lung. Dev Dyn. 2009;238(1):123-37.

21. Leimeister C, Schumacher N, Steidl C, Gessler M. Analysis of HeyL expression in wild-type and Notch pathway mutant mouse embryos. Mech Dev. 2000;98(1-2):175-8.

22. Cohen ED, Ihida-Stansbury K, Lu MM, Panettieri RA, Jones PL, Morrisey EE. Wnt signaling regulates smooth muscle precursor development in the mouse lung via a tenascin C/PDGFR pathway. J Clin Invest. 2009:1 19(9):2538-49.

23. Pickett EA, Olsen GS, Tallquist MD. Disruption of PDGFRalpha-initiated PI3K activation and migration of somite derivatives leads to spina bifida. Development. 2008;135(3):589-98.
24. Patel S. Exploring novel therapeutic targets in GIST: focus on the PI3K/Akt/ mTOR pathway. Curr Oncol Rep. 2013;15(4):386-95.

25. McCarthy N, Wetherill L, Lovely CB, Swartz ME, Foroud TM, Eberhart JK. Pdgfra protects against ethanol-induced craniofacial defects in a zebrafish model of FASD. Development. 2013;140(15):3254-65.

26. Tordet C, Bertin R, Gardey C, Richard MO, Dameron F, Marin L. Lung catecholamines and cyclic nucleotides during perinatal development in the rat. Possible relationships with biochemical and morphological differentiation. Pediatr Res. 1981;15(5):787-93.

27. Tiozzo C, Carraro G, Al Alam D, Baptista S, Danopoulos S, Li A, et al. Mesodermal Pten inactivation leads to alveolar capillary dysplasia- like phenotype. J Clin Invest. 2012;122(11):3862-72.

28. Gupta RK, Arany Z, Seale P, Mepani RJ, Ye L, Conroe HM, et al. Transcriptional control of preadipocyte determination by Zfp423. Nature. 2010:464(7288):619-23.

29. Gupta RK, Mepani RJ, Kleiner S, Lo JC, Khandekar MJ, Cohen P, et al. Zfp423 expression identifies committed preadipocytes and localizes to adipose endothelial and perivascular cells. Cell Metab. 2012;15(2):230-9.

30. Grunberg JR, Hammarstedt A, Hedjazifar S, Smith U. The novel secreted adipokine WNT1-inducible signaling pathway protein 2 (WISP2) is a mesenchymal cell activator of canonical WNT. J Biol Chem. 2014;289(10):6899-907.

31. Hammarstedt A, Hedjazifar S, Jenndahl L, Gogg S, Grunberg J, Gustafson B, et al. WISP2 regulates preadipocyte commitment and PPARgamma activation by BMP4. Proc Natl Acad Sci U S A. 2013;110(7):2563-8.

32. Chen WV, Delrow J, Corrin PD, Frazier JP, Soriano P. Identification and validation of PDGF transcriptional targets by microarray-coupled gene-trap mutagenesis. Nat Genet. 2004;36(3):304-12.

33. Li C, Li M, Li S, Xing Y, Yang CY, Li A, et al. Progenitors of secondary crest myofibroblasts are developmentally committed in early lung mesoderm. Stem Cells. 2015;33(3):999-1012.

34. Iwata J, Tung L, Urata M, Hacia JG, Pelikan R, Suzuki A, et al. Fibroblast growth factor 9 (FGF9)-pituitary homeobox 2 (PITX2) pathway mediates transforming growth factor beta (TGFbeta) signaling to regulate cell proliferation in palatal mesenchyme during mouse palatogenesis. J Biol Chem. 2012;287(4):2353-63.

35. Chapman HA. Epithelial responses to lung injury: role of the extracellular matrix. Proc Am Thorac Soc. 2012;9(3):89-95.

36. Shalaby F, Rossant J, Yamaguchi TP, Gertsenstein M, Wu XF, Breitman ML, et al. Failure of blood-island formation and vasculogenesis in Flk-1-deficient mice. Nature. 1995;376(6535):62-6.

37. $Y u$ K, Xu J, Liu Z, Sosic D, Shao J, Olson EN, et al. Conditional inactivation of FGF receptor 2 reveals an essential role for FGF signaling in the regulation of osteoblast function and bone growth Development. 2003:130(13):3063-74.

38. Morimoto M, Liu Z, Cheng HT, Winters N, Bader D, Kopan R. Canonical Notch signaling in the developing lung is required for determination of arterial smooth muscle cells and selection of Clara versus ciliated cell fate. J Cell Sci. 2010;123(Pt 2):213-24.

39. Li M, Li C, Liu YH, Xing Y, Hu L, Borok Z, et al. Mesodermal deletion of transforming growth factor-beta receptor II disrupts lung epithelial morphogenesis: cross-talk between TGF-beta and Sonic hedgehog pathways. J Biol Chem. 2008;283(52):36257-64.

40. McGowan SE, Torday JS. The pulmonary lipofibroblast (lipid interstitial cell) and its contributions to alveolar development. Annu Rev Physiol. 1997:59:43-62.

41. Li DM, Sun H. TEP1, encoded by a candidate tumor suppressor locus, is a novel protein tyrosine phosphatase regulated by transforming growth factor beta. Cancer Res. 1997;57(11):2124-9.

42. Addison WN, Fu MM, Yang HX, Lin Z, Nagano K, Gori F, et al. Direct transcriptional repression of Zfp423 by Zfp521 mediates a bone morphogenic protein-dependent osteoblast versus adipocyte lineage commitment switch. Mol Cell Biol. 2014:34(16):3076-85.

43. Cserjesi P, Lilly B, Bryson L, Wang Y, Sassoon DA, Olson EN. MHox: a mesodermally restricted homeodomain protein that binds an essential site in the muscle creatine kinase enhancer. Development. 1992;115(4):1087-101.

44. Du B, Cawthorn WP, Su A, Doucette CR, Yao Y, Hemati N, et al. The transcription factor paired-related homeobox 1 (Prrx1) inhibits adipogenesis by activating transforming growth factor-beta (TGFbeta) signaling. J Biol Chem. 2013;288(5):3036-47.

45. Kawaguchi N, Nakao R, Yamaguchi M, Ogawa D, Matsuoka R. TGF-beta superfamily regulates a switch that mediates differentiation either into 
adipocytes or myocytes in left atrium derived pluripotent cells (LA-PCS). Biochem Biophys Res Commun. 2010;396(3):619-25.

46. Xing Y, Li C, Li A, Sridurongrit S, Tiozzo C, Bellusci S, et al. Signaling via Alk5 controls the ontogeny of lung Clara cells. Development. 2010;137(5):825-33.

47. Li C, Li A, Li M, Xing Y, Chen H, Hu L, et al. Stabilized beta-catenin in lung epithelial cells changes cell fate and leads to tracheal and bronchial polyposis. Dev Biol. 2009;334(1):97-108.

48. Smith SM, Crowe DL, Lee MK. beta1 integrins modulate p66ShcA expression and EGF-induced MAP kinase activation in fetal lung cells. Biochem Biophys Res Commun. 2006;342(3):909-18.

49. Lehr HA, Mankoff DA, Corwin D, Santeusanio G, Gown AM. Application of Photoshop-based image analysis to quantification of hormone receptor expression in breast cancer. J Histochem Cytochem. 1997;45(11):1559-65.

Submit your next manuscript to BioMed Central and we will help you at every step:

- We accept pre-submission inquiries

- Our selector tool helps you to find the most relevant journal

- We provide round the clock customer support

- Convenient online submission

- Thorough peer review

- Inclusion in PubMed and all major indexing services

- Maximum visibility for your research

Submit your manuscript at www.biomedcentral.com/submit
Biomed Central 